\title{
Impact of Abusive Supervision, Ostracism and Workplace Bullying on Employee Performance with moderating effect of Spiritual Intelligence.
}

\section{Zara Tahir1, Fatima Bashir², Saadullah Shah ${ }^{3}$ \\ ${ }^{1}$ Lecturer, Faculty of Management Sciences, International Islamic University, Islamabad \\ ${ }^{2}$ Lecturer, Air University School of Management (AUSOM), Air University Islamabad \\ ${ }^{3}$ Ph.D. Scholar, Institute of Management Studies, University of Peshawar, Peshawar.}

\section{A B S T R A C T}

The purpose of this study is to present an analysis of the impact of organizational factors such as abusive supervision, Ostracism, and workplace bullying on the performance of an employee. We have also tested the moderating impact of spiritual intelligence on the relationship between these organizational factors and employee performance. The survey was conducted in the banking sector of Pakistan. A questionnaire distribution method was used to conduct this research. The total numbers of respondents were 365 of which the respondents were professionals belonging to different banks. The findings of this research paper indicate that due to the presence of factors such as employees getting demotivated and their performance lowers down. But if they have high spiritual intelligence their experiences can be enhanced at their workplace. This paper encourages the companies that they should on the development and promotion of the spiritual intelligence and policies that support employees to change work attitudes.

Keywords: Abusive supervision, Ostracism, Workplace bullying, Spiritual intelligence, Employee performance.

\section{INTRODUCTION}

Spiritual intelligence is also a type of intelligence with which people tackle problems of meaning, value and put their dealings and live their days meaningfully (Zohar \& Marshall, 2000; Atroszko, Skrzypińska, \& Balcerowska, 2021) Spiritual intelligence has an impact on different organizations functions such as the performance functionality and culture, etc (Seyed,2014; Skrzypińska, 2021) there is a link between EI the SI and the work performance of the employees (McKeage, 2002; Eid, Arnout, \& Almoied, 2021; Oyewunmi, Esho, \& Oyewunmi, 2021 ). Spiritual intelligence has proved 
to be a valuable education that facilitates the attainment of human excellence (Hanefar, 2015; Solih, 2021; Kumar, 2021).

To be successful the organizations must understand the importance of the performance of their employees. Several factors impact the performance of the employees (Melton \& Hartline, 2010; Timang, Nadeak, \& Sihotang, 2021). The behavior of the supervisor at the job highly affects how the employee perceives his job and that in turn directly impacts the performance of the employees. (Ellinger \& Keller, 2003) the employees who have the supervisors involved in the abusive supervision have been observed to have left the job they suffer from a higher level of work and family life disbalance their levels of satisfaction about the job and their personal life also decreases (Tepper, 2000).

Workplace bullying is referred to as any acts involving spreading of rumors about individuals, sabotaging the work-life of peers at any level making it difficult for them to work, expressing verbal expression as well as putting undue pressure on people at work (Hutchinson et al., 2010 ) employees exposed to it show mental distress and illness. This distress is aggravated by failures in unreasonable workplace procedures. (Hurley, 2016)

As ostracism represents a form of exclusion, ostracism researchers have similarly predicted a negative relationship between ostracism and self-esteem level (Ferris, 2015; Salem et al., 2021) confirmed that there is a negative impact of ostracism has a negative impact on the performance of the employee since the perception of the employees about their exclusion at the workplace leads to their work deviant behaviors. Ostracism is the most direct form of pressuring an employee's face from their peers (Masclet, 2003; Jiang, 2021; Yakoobi, 2021). Every individual desire an equal exchange of benefits and inequality puts the relationship at risk. The social exchange theory poses that human beings choose to maintain and create the relationships in which they perceive the maximization of the rewards and minimization of the costs and they tend to keep the valuable relationships for the long term (Emerson, 1976).

There are many studies conducted that have attempted to study the impact of workplace bullying, abusive supervision, and ostracism on the performance and health of 
employees (Shin, Hur \& Hwang, 2021; Fisher et al., 2021; Bai, Lu \& Lin, 2021: Bbano et al., 2021; AlBreiki., \& Behforouzi, 2021; Atwi \& Amoah, 2021) but the collective impact of these factors on the performance of employees is missing in the literature. Moreover, the study of the impact that spiritual intelligence causes on the negative relationship of the proposed variables on the performance of an employee is also missing in the literature. We will be conducting the study in the baking and telecom sectors of Pakistan. Since Pakistan is a Muslim country the application of spiritual intelligence will support the improvement in the performance of the employees.

\section{LITERATURE REVIEW}

\subsection{Ostracism}

The Employee of an organization acts as the bloodstream of any business. The success or disaster of the firm depends on the performance of the employee (Elnaga, 2014; Wesselmann, 2021). Therefore, the factors that impact the performance of the employees need substantial consideration for policy development to improve their both work and personal life.

Ostracism refers to the situation where one feels excluded from a group of people (Ferris, 2008) employee has a feeling that he is getting silent treatment in office (Fox \& Stallworth, 2005; Gamian \& Madeja, 2021). It is a form of peer pressure and occurs when some disliked members are excluded from the social group (Francis, 1985).

Ferris and Brown (2015), revealed through their study that ostracism has some serious behavioral consequences where victims feel low self-esteem and loss of focus on work which leads to a decline in performance. Choi, Cheung, and Williams (2000) indicated that ostracism is accompanied by many undesirable implications the victims form aggressive intentions towards the society (Williams, Wirth, Gutenberg \& Sacco, 2010; Law, Merkand, Shen, \& Brown, 2021; Cai, Sun, \& Li, 2021) and the ones who have ostracized them (Twenge, Stucke, Tice \& Baumeister, 2001). Such individuals are more expected to show compromised ability to regulate the spontaneous actions of themselves and they often feel distressed (Zadro, Jones, Williams \& Oaten, 2008)

Sommer and Williams (1997) revealed in their study that our self-perceptions are 
highly negatively affected by ostracism, which is verified with resulting negative behaviors. However, the relation of ostracism to behavior is conflicting (Ferris 2008; Dewall, Manner, Schaller \& Baumeister 2007). This is consistent with the literature, which shows the mixed findings between the level of self-esteem and its outcomes (Campbell, Baumeister, Vohs \& Baurmeister 2003; Huang, Zhang \& Zhu, 2021) these overall findings put a doubt on the theory of self-verification's ability to give a framework for the effects of ostracism on its outcomes. They bring into question whether a self-verification motivation, which was considered to be a central determinant of human behavior (Swann, 1983), is even real.

$\mathbf{H}_{1}$ : Workplace ostracism has a negative impact on the performance of the employee.

\subsection{Abusive Supervision}

Keashly (2001) studied emotional abuse and found that the feeling of being abused is significant. Employees show unfavorable attitudes towards their job if their supervisor is abusive (Tepper, 2000). Earlier the literature has shown the term workplace aggression for such kinds of behaviors. Neuman (1998) found that it is behaviors, which have an intent to cause damage to the people the person, is working with or has worked with. The victims of abusive supervision have been shown to have a direct impact on their work and family life balance (Kwan, Resick \& Kwong, 2012 Birnbaum, Chow, \& Gilliland, 2021). The abusive supervision at the workplace has a significant impact on the performance and work-related attitudes of the employees as well (Sharon Chen, Kernan, \& Kim, 2011). The politically skilled workers who tend to be evaluators of themselves have shown to be abusers of others at the workplace more frequently (Jawahar, Jennifer, Mharapara, Liguori \& Stone, 2010; Wihler, Bormann, \& Ammann, 2021).

Harvey and Ray (2016) have asserted in their findings that there is a direct relationship of the level of anger in the subordinate, entitlement, negative affect, and the hostile attribution style with the perception they gave about the workplace abuse.

$\mathbf{H}_{2}$ : Abusive supervision has a negative impact on employee performance.

\subsection{Workplace Bullying}

No set of behaviors can be defined that formulate workplace bullying. It is normally referred to as acts of verbal aggression, humiliating other, sabotaging the work 
done by others, damaging the reputation of others, making the life of other people difficult by putting them under pressure (Hutchinson et al). Such acts of workplace bullying induce a feeling of low morale, tension, sickness overwork, and most importantly disgust in the people who are victims of workplace bullying (Hannabuss, 1998).

Workplace bullying takes place when one person is thoroughly exposed to aggressive behavior, which can be from their supervisor, or a colleague for some long period and the victim feels that he cannot defend himself from the situation anymore or even take an escape from it (Zedlacher \& Snowden, 2021). Such kinds of treatments cause stigmatization in the target and lead to serious psychological trauma (Einarsen, 1999). The variations that are observed in workplace bullying are based on cross-cultural differences. The cultural norms presented by Hofstede (power distance, collectivism vs. individualism, femininity vs. masculinity, uncertainty avoidance, and long short-term orientation) have proven to have a direct relationship with the tendency to bully someone, the fear that employees have when they want to express some disagreement as well as their overall decision-making process (Comer \& Vega, 2005; Salin, 2021).

Workplace bullying not only forms psychological damage but also caused serious health-related issues (Hutchinson, 2005). The loss in terms of finance, the increase in the staff turning over, the reduction in productivity and loyalty, and the decrease in morale can all be related to workplace bullying (Cooper \& Rayner, 1997, Quine, 1999). It has been observed that the victims of workplace bullying normally give up in the situation and tend to leave the organization instead of fighting for it (Karatuna, 2015).

$\mathbf{H}_{3}$ : Workplace bullying has a negative relation with employee performance.

\subsection{Spiritual Intelligence}

Spirituality has been defined as an innate human need to connect to things that are larger than ourselves, things that we consider divine and exceptionally Nobel (Wigglesworth, 2012). Literature reflects different concepts about spirituality as Baum (1986) indicated that "a gifted individual is the one who reflects or has the potential to reflect an outstanding performance in multiple areas". During the early ears, psychological measures of human intelligence based on creativity and motivation gave 
the basis to researchers for understanding the concept of giftedness (Robinson \& Clinkenbeard, 2008). The concept of spiritual intelligence was proposed in 1996 by Stevens, followed by Emmons in 1999. Spiritual intelligence is defined as the conformity application of spiritual information that aims to facilitate solving daily issues and the attainment of goals (Emmons, 2000).

$\mathbf{H}_{4}$ : Spiritual intelligence has a positive impact on employee performance.

According to Bowell (2004), spiritual intelligence includes seven steps: awareness, meaning, evaluation, being centered, vision, projection, and mission. Which assists the individuals to solve the daily issue they come across.

H5: Spiritual intelligence has a negative impact on workplace bullying and moderates its relationship with employee performance.

Spiritual intelligence as defined by Wiggleworth (2006) is the ability to behave with wisdom and clemency as long as internal and external peace is maintained taking into consideration the conditions (equanimity).

$\mathbf{H}_{6}$ : Spiritual intelligence has a negative relation with ostracism and moderates its relationship with employee performance.

The SQ is an internal, innate ability of the human brain and psyche, drawing its deepest resources from the heart of the universe itself (Zohar, 2000) they help the person to overcome many issues such as the conditions external to one's self. Spiritual intelligence moderates the relationship between workplace abuse and deviance, hence it can be checked for impact between performance and abuse as well (Hamid, Juhd, Ismail \& Abdullah, 2016).

H7: Spiritual intelligence has negative relation with abusive supervision and moderates its relationship with employee performance.

\subsection{Employee Performance}

Improved capabilities, knowledge, and skills of the talented workforce proved to be a major source of competitive advantage in a global market (McKinsey, 2006). The team is an important part of an organizational design. One aspect that an organization can't ignore is the importance of team members; they are the precious assets of any organization. (Riaz, 2010). Mwita (2000) states that employee performance is an essential 
tool for an organization and determinants because of which an organization's performance can be analyzed. The employees are the ones who represent the organization in both good and bad ways depending on their level of performance and understanding of the organizational goals (Melton \& Hartline 2010). The behavior of the supervisor at the job highly affected how the employee perceives his job and how much they are satisfied from their job and that in turn directly impacts the performance of the employees. (Andrea, Scott \& Kellerl, 2003).

According to Hawthorne studies, and much other research work on productivity of workers highlighted the fact that employees who are satisfied with their job will have higher job performance, and thus supreme job retention than those who are not happy with their jobs (Landy, 1985). Moreover, it is stated that employees are more likely to turnover if they are not satisfied and hence demotivated to show good performance. Employee performance is higher in happy and satisfied workers and the management finds it easy to motivate high performers to attain firm targets. (Kinicki \& Kreitner, 2007; Budur, \& Poturak, 2021). Employees could be only satisfied when they feel competent to perform their jobs, which is achieved through better training programs.

\subsection{Conceptual Framework}

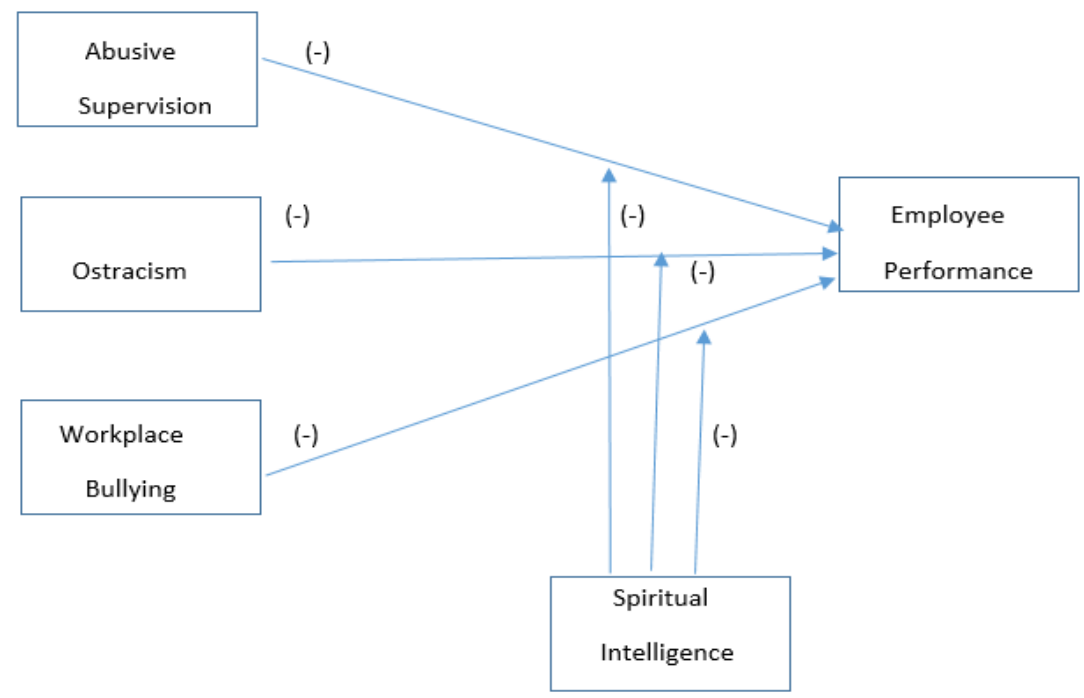




\section{RESEARCH METHODOLOGY}

\subsection{Samples and Procedures}

The researchers collected data from 365 professionals working at different levels in the banking sector of Pakistan. Due to the limitation of availability of complete lists of professionals the current study used a purposive sampling technique. 400 questionnaires were distributed by one of the authors under personal administration. The respondents included $78.8 \%$ males and $21.2 \%$ females. The average respondents in our sample were up to 25 years in age and their education was bachelors.

\subsection{Measures}

All the items were presented in the English language. Face and content validity were checked with subject matter experts in the field. The scales were adapted and were measured on the Likert scale ( $1=$ strongly disagree, $5=$ strongly agree)

Abusive supervision was adapted from the Tepper (2000) which included questions like "my manager often mocks me", "my supervisor invades my privacy", etc. the Cronbach's alpha of abusive supervision in our study was .776 (6 items).

Ostracism was adapted from Ferris, Brown, Berry, \& Lian (2008), and the items included were like, "my greetings are unresponded at my workplace", "I am treated as if I am not there at my workplace", etc. the Cronbach's alpha of Ostracism in our study was .625 (6 items).

Workplace bullying was adapted from the UMass Amherst's Campus Coalition since it is a developed scale, the items included, "being bullied at work has reduced my performance at work", being bullied has decreased my motivation", etc. the Cronbach's alpha of this variable in our study was .885 (6 items)

The scale for spiritual intelligence was adapted from Daleman and Frey 2004. It is a shorter version of the test for spiritual intelligence, it included items like, "there is nothing much that I can do to help myself", I do not have any purpose in my life" etc, the Cronbach's alpha of this variable in our study was .889 (12 items).

The scale of employee performance was adapted from Zaki (2013) which included items such as, "I am able to meet the requirements of my job", "I have good 
interaction within and across the teams in my organization. The Cronbach's alpha of the study was .793 (5 items)

\section{RESULTS AND DISCUSSION}

\begin{tabular}{|l|c|c|c|c|c|c|c|}
\hline \multicolumn{7}{|l|}{ Table 1. Correlation Analysis } \\
\hline Variables & Mean & S.d & 1 & 2 & 3 & 4 & 5 \\
\hline $1 . \mathrm{AS}$ & 3.15 & 1.10 & 1 & & & & \\
\hline 2. Ost & 3.49 & .850 & $.622^{* *}$ & 1 & & & \\
\hline 3. WPB & 3.22 & 1.20 & $.809^{* *}$ & $.718^{* *}$ & 1 & & \\
\hline 4. SI & 1.97 & .830 & $-.633^{* *}$ & $-.553^{* *}$ & $-.753^{* *}$ & 1 & \\
\hline 5. OC & 2.22 & 1.09 & $-.851^{* *}$ & $-.591^{* *}$ & $-791^{* *}$ & $.715^{* *}$ & 1 \\
\hline
\end{tabular}

The correlation analysis was also run for all variables which have shown reliable correlation amongst all the IVs, the MV, and the DV with the minimum correlation between spiritual intelligence and ostracism which is -553 , and maximum correlation between the work organization commitment and the abusive supervision which is -.851 . The correlation of the control variables i.e. Gender, age, and education was not significant with any of the variables of the study so we will not include those in the regression analysis.

\begin{tabular}{|c|c|c|c|}
\hline Table 2. Regression Analysis & \multicolumn{3}{|l|}{} \\
\hline & & DV & \\
\cline { 2 - 4 } & $\mathrm{B}$ & R-sq & Change in Rsq \\
\hline Step 1 Direct Impact & \multicolumn{3}{|c|}{} \\
\hline AS & -.851 & .724 & \\
\hline OST & -.591 & .350 & \\
\hline WPB & -.791 & .625 & \\
\hline SI & .715 & .511 & .056 \\
\hline STEP-2 Interactive Impact & \multicolumn{3}{|c|}{} \\
\hline INT1 & .295 & .776 & .003 \\
\hline INT2 & -.214 & .561 & .065 \\
\hline INT3 & -.505 & .718 & \\
\hline
\end{tabular}

To test hypothesis\# 1 we used the regression analysis to check the individuallevel data. The statement of the hypothesis was Abusive supervision is negatively related to employee performance. The hypothesis was supported with the results $(t=-20.672$, $\mathrm{F}=427.348, \mathrm{p}=0.001$ details in Table). The second statement of the hypothesis was that 
Ostracism is negatively related to the performance of the employees it was also supported with the results $(\mathrm{t}=-9.360, \mathrm{~F}=87.613, \mathrm{p}=0.001$ Model 2 details in Table). The statement of hypothesis 3 was that workplace bullying is negatively related to employee performance $(t=-16.485, F=271.767, p=0.001$ details in Table).

Hypothesis 4 stated that spiritual intelligence has a positive impact on the organization's commitment which was supported by the results $(\mathrm{t}=-13.040, \mathrm{~b}=.749, \mathrm{p}=$ 0.001 Model 4 details in Table). Hypothesis 5 stated that Abusive supervision is negatively related to spiritual intelligence. The hypothesis was supported with the results $(\mathrm{t}=-13.216, \mathrm{~b}=-.753, \mathrm{p}=0.001$ Model 5 details in Table). The sixth statement of the hypothesis was that Ostracism is negatively related to the performance of the employees it was also supported with the results $(\mathrm{t}=-9.613, \mathrm{~b}=-.640, \mathrm{p}=0.001$ Model 6 details in Table). The statement of hypothesis 7 was that workplace bullying is negatively related to spiritual intelligence $(t=-13.758, b=-.766, p=0.001$ Model 7 details in Table)

To test mediation we have used the barren and Kenny approach. Hypothesis 8 states that spiritual intelligence negatively moderates the relationship between the organization commitment and abusive supervision it is also supported $(\mathrm{t}=-5.624, \mathrm{~F}=$ 31.630, $\mathrm{p}=0.001$ details in Table). Hypothesis 9 states that spiritual intelligence negatively moderates the relationship between the organization commitment and abusive ostracism it is also supported ( $\mathrm{t}=4.721, \mathrm{~F}=22.291, \mathrm{p}=0.001$ Model 9 details in Table). Hypothesis 10 states that spiritual intelligence negatively moderates the relationship between the organization commitment and workplace bullying it is supported ( $\mathrm{t}=-7.290$, $\mathrm{F}=53.144, \mathrm{p}=0.001$ Model 9 details in Table). The variables had a significant relationship with the IVs but with the intervention of the moderator, the relationship weakened showing that the moderator reduced the negative impact.

\subsection{Implications of the study.}

There are many practical and theoretical implications of the study. Theoretically speaking the study is one of the initial studies where the impact of spiritual intelligence is studied to reduce and control the impact of the negative organizational factors such as abusive supervision, workplace bullying, and ostracism. This study will serve to open new avenues of research for the researchers to explore the impact of spiritual intelligence 
to enhance employee performance in presence of different organizational factors.

Practically speaking the study can support the management to understand the organizational factors that bring the employees down and with the help of the understanding of the spiritual intelligence they can devise policies that can help to elevate the spiritual quotient of the employees which has proven to increase the productivity of the employees.

\subsection{Limitations of the Study}

The time and resource constraints were the limitations of the study. The study needs to be expanded over time. There may be some present factors that influence the response of the respondents and to overcome this limitation the longitudinal is recommended.

\section{CONCLUSION}

The study has provided insights into the impact of spiritual intelligence on the performance of the employees in presence of the negative organizational factors such as workplace bullying, ostracism, and abusive supervision. The results have revealed that the subject variables have a significant negative impact on the performance of the employees of the organization, which should not be ignored because it may lead towards reduction in productivity and higher turn over which will be the ultimate loss of the organization. However, if spiritual intelligence is incorporated in the lives of the employees and they are trained to use the ability and recognize its significance the negative impact of the organizational factors can be reduced as observed in the results the interactive effect is significant hence it can help in the control of the performance of the employees.

\section{REFERENCES}

Baron, R. A., \& Neuman, J. H. (1998). Workplace aggression--the iceberg beneath the tip of workplace violence: Evidence on its forms, frequency, and targets. Public Administration Quarterly, 446-464.

Baum, S. (1986). The gifted preschooler: An awesome delight. Gifted Child Today, 9 (4), 42-45 (cited by: Escobedo, S. E., 2008, Methods and procedures in screening gifted Mayan students, Gifted and Talented International, 88.

Baumeister, R. F., Campbell, J. D., Krueger, J. I., \& Vohs, K. D. (2003). Does high selfesteem cause better performance, interpersonal success, happiness, or healthier 
lifestyles? Psychological science in the public interest, 4(1), 1-44.

Birnbaum, A., Chow, C., \& Gilliland, S. (2021). The Psychological Mediators between Abusive Supervision and Unethical Pro-Organizational Behavior. In Academy of Management Proceedings (Vol. 2021, No. 1, p. 15909). Briarcliff Manor, NY 10510: Academy of Management

Bowell, R. A. (2004). The seven steps of spiritual intelligence: The practical pursuit of purpose, success, and happiness. Nicholas Brealey Publishing.

Brees, J., Martinko, M., \& Harvey, P. (2016). Abusive supervision: subordinate personality or supervisor behavior? Journal of Managerial Psychology, 31(2), 405-419.

Byrne, A., Barling, J., \& Dupré, K. E. (2014). Leader apologies and employee and leader well-being. Journal of business ethics, 121(1), 91-106.

. Cai, Y., Sun, F., \& Li, J. S. (2021). The interactive effect of abusive supervision and leaders' prototypicality on coworkers' ostracism. In Academy of Management Proceedings (Vol. 2021, No. 1, p. 12964). Briarcliff Manor, NY 10510: Academy of Management.

Einarsen, S. (1999). The nature and causes of bullying at work. International journal of manpower, 20(1/2), 16-27.

Ellinger, A. D., Ellinger, A. E., \& Keller, S. B. (2003). Supervisory coaching behavior, employee satisfaction, and warehouse employee performance: $A$ dyadic perspective in the distribution industry. Human resource development quarterly, 14(4), 435-458.

Emerson, R. M. (1976). Social exchange theory. Annual review of sociology, 335-362..

Emmons, R. A. (2000). Is spirituality an intelligence? Motivation, cognition, and the psychology of ultimate concern. The International Journal for the psychology of Religion, 10(1), 3-26.

Emmons, R. A. (2000). Spirituality and intelligence: Problems and prospects. The international journal for the psychology of religion, 10(1), 57-64.

Ferris, D. L., Brown, D. J., Lian, H., \& Keeping, L. M. (2009). When does self-esteem relate to deviant behavior? The role of contingencies of self-worth. Journal of Applied Psychology, 94(5), 1345.

Ferris, D. L., Lian, H., Brown, D. J., Pang, F. X., \& Keeping, L. M. (2010). Self-esteem and job performance: the moderating role of self-esteem contingencies. Personnel Psychology, 63(3), 561-593.

Ferris, D. L., Lian, H., Brown, D. J., \& Morrison, R. (2015). Ostracism, self-esteem, and job performance: when do we self-verify and when do we selfenhance?. Academy of Management Journal, 58(1), 279-297.

Fox, S., \& Stallworth, L. E. (2005). Racial/ethnic bullying: Exploring links between bullying and racism in the US workplace. Journal of Vocational Behavior, 66(3), 438-456.

Hanefar, S. B., Siraj, S., \& Sa'ari, C. Z. (2015). The Application of Content Analysis toward the Development of Spiritual Intelligence Model for Human Excellence (SIMHE). Procedia-Social and Behavioral Sciences, 172, 603-610.

Hannabuss, S. (1998). Bullying at work. Library Management, 19(5), 304-310.

Hutchinson, M., Vickers, M., Jackson, D., \& Wilkes, L. (2006). Workplace bullying in nursing: towards a more critical organizational perspective.Nursing inquiry, 13(2), 118-126.

Hurley, J., Hutchinson, M., Bradbury, J., \& Browne, G. (2016). Nexus between preventive policy inadequacies, workplace bullying, and mental health: Qualitative findings from the experiences of Australian public sector employees. International journal 
of mental health nursing.

Isaac Mwita, J. (2000). Performance management model: a systems-based approach to public service quality. International Journal of Public Sector Management, 13(1), 19-37.

Kalantarkousheh, S. M., Sharghi, N., Soleimani, M., \& Ramezani, S. (2014). The Role of Spiritual Intelligence on Organizational Commitment in Employees of Universities in Tehran Province, Iran. Procedia-Social and Behavioral Sciences, 140, 499-505

Karatuna, I. (2015). Targets' coping with workplace bullying: a qualitative study. Qualitative Research in Organizations and Management: An International Journal, 10(1), 21-37.

Keashly, L. (2001). Interpersonal and systemic aspects of emotional abuse at work: The target's perspective. Violence and Victims, 16(3), 233-268.

Kernan, M. C., Watson, S., Fang Chen, F., \& Gyu Kim, T. (2011). How cultural values affect the impact of abusive supervision on worker attitudes.Cross Cultural Management: An International Journal, 18(4), 464-484.

Khan, M. R., Ziauddin, J. F., Jam, F. A., \& Ramay, M. I. (2010). The impacts of organizational commitment on employee job performance. European Journal of Social Sciences, 15(3), 292-298.

Kisamore, J. L., Jawahar, I. M., Liguori, E. W., Mharapara, T. L., \& Stone, T. H. (2010). Conflict and abusive workplace behaviors: The moderating effects of social competencies. Career Development International, 15(6), 583-600.

Kinicki, A. and Kreitner, R. (2007), Organizational Behavior, McGraw-Hill, New York, NY.

Landy, F. W. (1985). The psychology of work behavior (3rd ed.). Homewood, IL: Dorsey Press

Law, D., Merkand, R., Shen, W., \& Brown, D. J. (2021). A Meta-Analytic Integration of Mechanisms Linking Workplace Ostracism and OCB. In Academy of Management Proceedings (Vol. 2021, No. 1, p. 13357). Briarcliff Manor, NY 10510: Academy of Management.

Masclet, D. (2003). Ostracism in work teams: a public good experiment. International Journal of Manpower, 24(7), 867-887

Melton, H. L., \& Hartline, M. D. (2010). Customer and frontline employee influence on new service development performance. Journal of Service Research, 13(4), 411425.

Oaten, M., Williams, K. D., Jones, A., \& Zadro, L. (2008). The effects of ostracism on selfregulation in the socially anxious. Journal of Social and Clinical Psychology, 27(5), 471.

Quarterly, M. (2006). An executive take on the top business trends, a McKinsey Global Survey. The McKinsey Quarterly.

Quine, L. (1999). Workplace bullying in NHS community trust: staff questionnaire survey. Bmj, 318(7178), 228-232.

Rayner, C., \& Cooper, C. (1997). Workplace bullying: myth or reality-can we afford to ignore it?. Leadership \& Organization Development Journal, 18(4), 211-214.

Robinson, A., \& Clinkenbeard, P. R. (2008). History of giftedness: Perspectives from the past presage modern scholarship. In Handbook of giftedness in children (pp. 1331). Springer US.

Salin, D. (2021). Workplace bullying and culture: Diverse conceptualizations and interpretations. Dignity and Inclusion at Work, 513-538.

Swarm Jr, W. B. (1983). Self-verification: Bringing social reality into harmony with the self. Social psychological perspectives on the self, 2, 33-66. 
Tischler, L., Biberman, J., \& McKeage, R. (2002). Linking emotional intelligence, spirituality and workplace performance: Definitions, models and ideas for research. Journal of Managerial psychology, 17(3), 203-218.

Tepper, B. J. (2000). Consequences of abusive supervision. Academy of management journal, 43(2), 178-190.

Twenge, J. M., Baumeister, R. F., DeWall, C. N., Ciarocco, N. J., \& Bartels, J. M. (2007). Social exclusion decreases prosocial behavior. Journal of personality and social psychology, 92(1), 56.

Vega, G., \& Comer, D. R. (2005). Sticks and stones may break your bones, but words can break your spirit: Bullying in the workplace. Journal of business ethics, 58(13), 101-109.

Wigglesworth, C. (2012). SQ21: The twenty-one skills of spiritual intelligence. BookBaby.

Wiggleworth, C. (2006). Why Spiritual Intelligence Is Essential to Mature Leadership President, Couscious Pursuits. Inc, 12(3), 30-43.

Wihler, A., Bormann, K. C., \& Gansen-Ammann, D. (2021). Justifying the Abuse: How Abusive Supervision Can Increase Supervisor-Directed Obligation. In Academy of Management Proceedings (Vol. 2021, No. 1, p. 13187). Briarcliff Manor, NY 10510: Academy of Management.

Williams, K. D., Cheung, C. K., \& Choi, W. (2000). Cyberostracism: effects of being ignored over the Internet. Journal of personality and social psychology, 79(5), 748.

Williams, K. D., \& Sommer, K. L. (1997). Social ostracism by coworkers: Does rejection lead to loafing or compensation?. Personality and Social Psychology Bulletin, 23(7), 693-706..

Williams, K. D., Forgas, J. P., \& Von Hippel, W. (Eds.). (2005). The social outcast: Ostracism, social exclusion, rejection, and bullying. Psychology Press.

Williams, L. J., \& Anderson, S. E. (1991). Job satisfaction and organizational commitment as predictors of organizational citizenship and in-role behaviors.Journal of management, 17(3), 601-617.

Wirth, J. H., Sacco, D. F., Hugenberg, K., \& Williams, K. D. (2010). Eye gaze as relational evaluation: Averted eye gaze leads to feelings of ostracism and relational devaluation. Personality and Social Psychology Bulletin.

Wu, L. Z., Kwong Kwan, H., Liu, J., \& Resick, C. J. (2012). Work-to-family spillover effects of abusive supervision. Journal of Managerial Psychology,27(7), 714-731.

Zadro, L., Boland, C., \& Richardson, R. (2006). How long does it last? The persistence of the effects of ostracism in the socially anxious. Journal of Experimental Social Psychology, 42(5), 692-697.

Zadro, L., Williams, K. D., \& Richardson, R. (2004). How low can you go? Ostracism by a computer is sufficient to lower self-reported levels of belonging, control, selfesteem, and meaningful existence. Journal of Experimental Social Psychology, 40(4), 560-567.

Zedlacher, E., \& Snowden, A. (2021). Practitioners' blame patterns and intervention measures for workplace bullying complaints. In Academy of Management Proceedings (Vol. 2021, No. 1, p. 16461). Briarcliff Manor, NY 10510: Academy of Management.

Zohar, D. (2012). Spiritual intelligence: The ultimate intelligence. Bloomsbury Publishing.

Zohar, D., Marshall, I. N., \& Marshall, I. (2000). SQ: Connecting with our spiritual intelligence. Bloomsbury Publishing USA. 